\title{
Rhizomatous geophytes from the genus Hosta in Western Siberia
}

\author{
Lyudmila Sedelnikova* \\ Central Siberian Botanical Garden, SB RAS, 630090 Novosibirsk, Russia
}

\begin{abstract}
This is research of biological features of the growth and development rhythm of 11 Hosta species in the conditions of forest-steppe zone of Western Siberia. A comparative analysis of the organogenesis of the species $H$. decorata, $H$. sieboldiana, and $H$. lancifolia is carried out. The seed productivity and viability of pollen of 9 species were established. It is provided the description of upper and lower epidermis, cross section of leaf. It is revealed that the structure of lamina is characterized by xeromesophytic characters. It is mentioned species specificity in arrangement of adaxial and abaxial stomas pursuant thereto leaves of two types of Hosta are amphistomatic and hypostomatic. It is concluded that on the lower epidermis of the leaf, the transpiration capacity is $3-8$ times greater.
\end{abstract}

\section{Introduction}

Representatives of the genus Hosta Tratt. (hosta, funkia), Hostaceae B. Mathew are perennial polycarpic herbaceous rhizomatous plants of the East Asian flora. They are cultivated in botanic gardens worldwide from of old. It is known that culture conditions exert impact on changes of adaptive characters of plants. The life form is the most plastic vegetative organ and in its structure reflects the ecological adaptation forming under the influence of species habitat conditions [1]. The aim is a comparative study of organogenesis, reproductive ability and of leaf anatomic structure of eleven species of the Hosta genus in the conditions of the forest-steppe zone of Western Siberia.

\section{Material and methods}

The research is performed in the Central Siberian botanic garden of the Siberian Branch of the Russian Academy of Science (Novosibirsk). As objects of research served plants of 11 species: Hosta decorata Bailey, H. sieboldiana (Hook.) Engl., H. lancifolia (Thunb.) Engl., $H$. albomarginata (Hook.) Hyl., H. crispula F. Maekawa, H. kikutii F. Maekawa, H. fortunei (Baker) Bailey, H. montana F. Maekawa, H. plantaginea (Lam.) Aschers., $H$. rectifolia Nakai, $H$. undulata (Otto et Dietr.) Bailey, $H$. ventricosa Stearn. Specimens were studied and photographed by Axioskop-40 (Carl Zeiss) microscope with AxioCam MRc-5 color digital cameras of high resolution and the AxioVision 4.8 program. The description

\footnotetext{
*Corresponding author: lusedelnikova@ yandex.ru
} 
of lead anatomical structure was made by the standard techniques [2 - 3]. Pollen fertility was determined by the acetocarmine method in $2 \%$ acetocarmine, in four fields of view, using a Zeiss Stemi DV4 microscope. The seeds and the apical zone of the monocarpic shoot were analyzed using a Carl Zeiss Stereo Discovery V 12 stereomicroscope, using micrographs.

\section{Results and discussion}

The beginning of host regrowth in the forest-steppe zone of Western Siberia is observed on May $15-30$, when the average daily temperature passes through $+15^{\circ} \mathrm{C}$ and the soil warms up to $+10^{\circ} \mathrm{C}$. The first stages of growth and development of hosts are slow. In the second decade of June, the plants have from five to nine leaves unfolded. The formation of leaves and the development of the leaf blade occurs during the entire growing season until the onset of autumn frosts. The beginning of budding was observed from the second decade of June to the first decade of August. The beginning of flowering of early-flowering species is noted in the first-second decades of July (H. decorata, H. albo-marginata, H. fortunei, $H$. plantaginea, $H$. undulata). Medium-flowering species ( $H$. ventricosa, $H$. crispula, $H$. siboldiana, $H$. kikutii) bloomed in the third decade of July. Late-flowering species $(H$. lancifolia) bloomed in the second decade of August. The duration of flowering of one generative shoot was $35-45$ days. The flowers are characterized by geitonogamy with the phenomenon of proteandry, hazmogamous pollination, herkogamy and flowering in the acropetal direction. In the inflorescence, there is a simultaneous flowering of the upper flowers and fruiting of the lower ones. It is known that the formation of plant organs is affected by the temperature gradient. Early-flowering species bloom at the sum of positive temperatures $>1156^{\circ} \mathrm{C}$, medium-flowering $>1238^{\circ} \mathrm{C}$, late-flowering $>1378^{\circ} \mathrm{C}$. Flowering of $H$. decorate occurs 26 to 27 days faster than in $H$. sieboldiana and 45 to 47 days faster than in $\mathrm{H}$. lancifolia. The vegetation period from spring regrowth to fruiting of the host in the conditions of Novosibirsk is $98-112$ days (fig. 1). According to the phenorhythmotype, the hosts are summer-flowering perennials.

Hosts belong to the short-root-brush-root polycarpics [4]. During the cultivation of hosts in the conditions of the Novosibirsk region, the development of underground plagiotropic stolon-forming shoots was noted. Their length is $20-35 \mathrm{~cm}$. The shoot thickness is $0.5-0.8 \mathrm{~cm}(H$. albomarginata $)$ and $1.5-2.0 \mathrm{~cm}$ (H. sieboldiana). In the apical zone of the shoots, the buds of renewal are laid. Young plants are formed from them. In H. lancifolia, an orthotropic direction of the axis of the underground shoot develops, on which adventive buds and thickened adventitious roots are formed. In the conditions of culture, the vegetative mobility and reproductive ability of the host increases. The coefficient of vegetative reproduction is from 3 to 25 pieces of shoots per growing season. Two types of generative shoots were found in the host: 1 - semi-rosette deciduous, with a regular leaf arrangement (H. albomarginata, H. undulata, H. fortunei, H. lancifolia); 2 rosette $(H$. decorata, $H$. plantaginea, $H$. sieboldiana, $H$. ventricosa).

A comparative analysis of organogenesis in the species $H$. decorata, $H$. sieboldiana, and $H$. lancifolia was performed. It is established that the intrarenal formation of generative organs is laid during the growth period of the monocarpic host shoot, in May - June. It is noted that the first flowers in the inflorescence (III - V stages of organogenesis) are formed quickly, within 3 to 5 days. It was found that the formation of generative organs from the VI to VIII stages of organogenesis is prolonged (fig. 2): in the early-flowering species $H$. decorata for $32-45$ days [5], in the middle-flowering $H$. sieboldiana for 56-68 days, in the late-flowering $H$. lancifolia for $58-76$ days. The flowers are formed acropetally. 

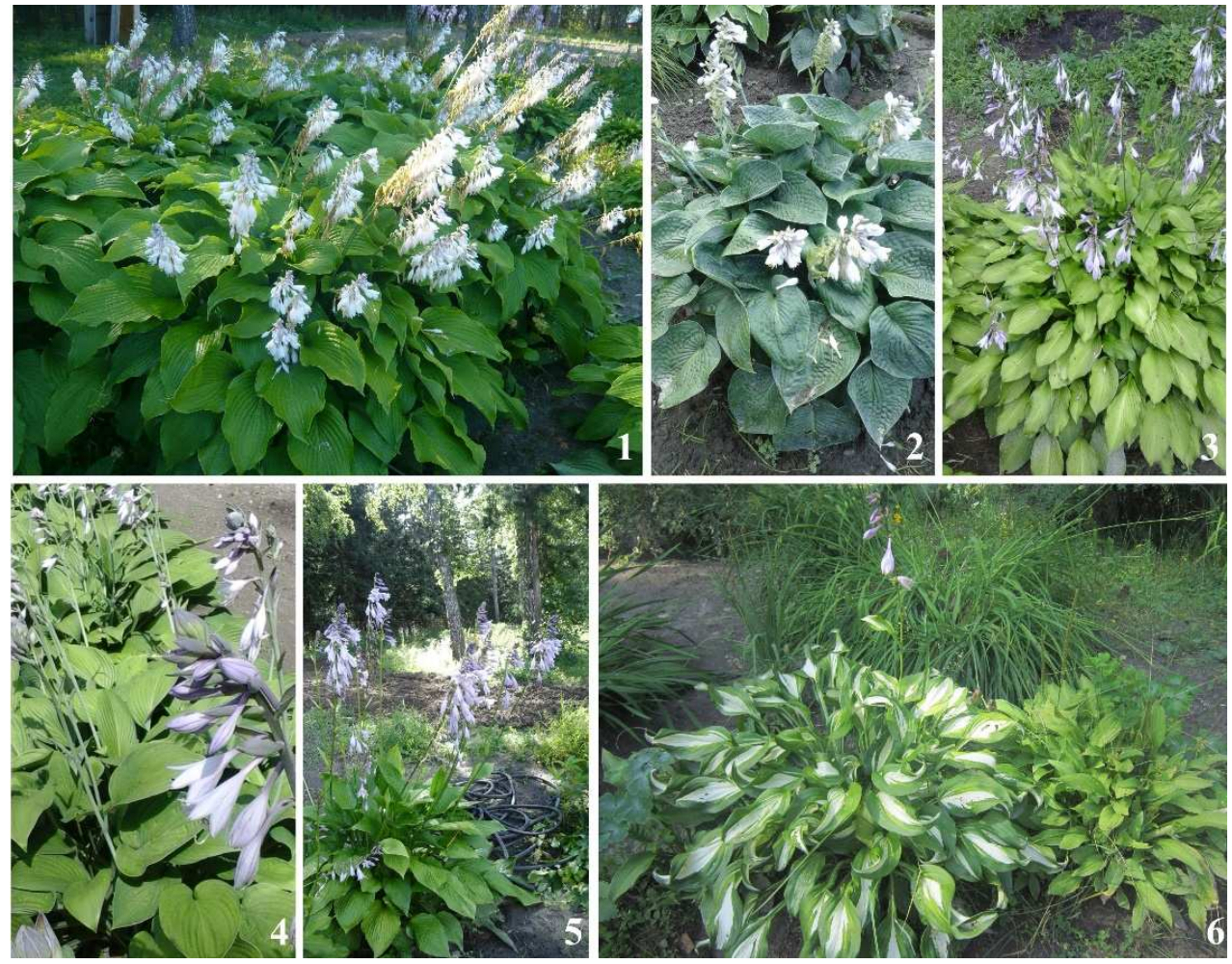

Fig. 1. Hosta decorata (1), Hosta siboldiana (2), Hosta lancifolia (3), Hosta fortunei (4), Hosta rectifolia (5), Hosta undulata (6) in the collection of the Central Siberian Botanical Garden.

Differentiation of the cone of growth of the shoot of renewal occurs synchronously with the III to VIII stages of organogenesis during 56 - 91 days. In the early-flowering species $H$. decorata, the organ formation process occurs $25-27$ days faster than in the lateflowering species H. lancifolia. The stages of organogenesis (from IX to XII) correspond to the phenophases from the beginning of flowering to fruiting. During the period of seasonal development, the shoot passes from the II to the XII stages of organogenesis. In the prewinter period, the shoots are renewed in $H$. decorata, $H$. sieboldiana, and $H$. lancifolia overwinter in a vegetative state. The cone of growth of the shoot of renewal is at the II stage of organogenesis, in its basal part from 4 to 6 leaf metamers are laid.
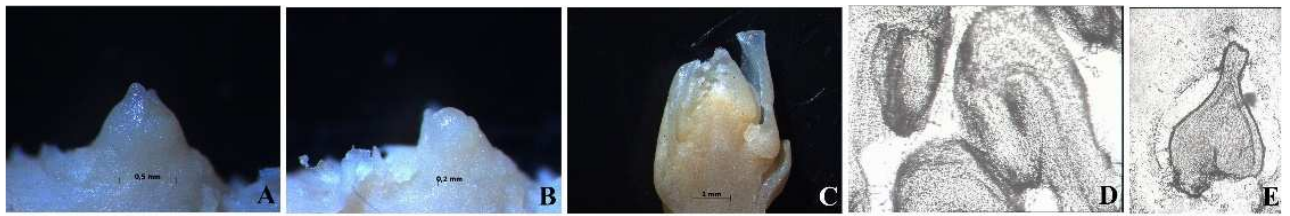

Fig. 2. Stages of organogenesis in Hosta lancifolia in the forest-steppe zone of Western Siberia. Note: a - III stage, b - IV stage, c - V- VII stage, $d$ - anthers, f - ovary

The results of free pollination of hosts were studied. The fruit is a freely opening loculicidal tricuspid capsule. Seeds are linear to oval in shape. The specificity of seed setting in hosts is associated with geitonogamous pollination of flowers. The coefficient of seed productivity is $16-93 \%$. A high adaptive advantage of seed productivity was observed in $\mathrm{H}$. decorata $(93 \%)$ and $\mathrm{H}$. kikutii $(82 \%)$. The actual seed productivity in the species (H. albomarginata, $H$. crispula, $H$. lancifolia, H. montana, $H$. rectifolia, $H$. 
sieboldiana, $H$. undulata) ranged from $1.7 \pm 0.2$ to $13.7 \pm 3.0 \mathrm{pcs}$. and it was $2-8$ times lower than the potential seed productivity. Fruit formation occurs in an acropetal sequence, with a fruiting duration of $30-65$ days. Pollen fertility was studied in the species $H$. albomarginata (19.2 \pm 2.5 units), $H$. decorata (16.5 \pm 1.6 units), H. rectifolia $(7.3 \pm 0.5$ units), and $H$. sieboldiana (12.0 \pm 1.1 units). It was shown that the fertilizing capacity of pollen ranged from 46.1 to $82.6 \%$. It was 1.5 times higher in $H$. albomarginata $(82.6 \pm$ $1.4 \%)$ and $H$. decorata $(78.5 \pm 2.1 \%)$ than in $H$. rectifolia $(52.1 \pm 1.1 \%)$ and $H$. sieboldiana $(46.1 \pm 1.8 \%)$. It was found that the indicator of low pollination efficiency is sterile pollen. Fertile pollen grains have an oblong and rounded shape, with a distinct furrow, entina and exina, and are well colored in acetocarmine. The sterile pollen was slightly colored, small, oblong in shape (fig. 3).
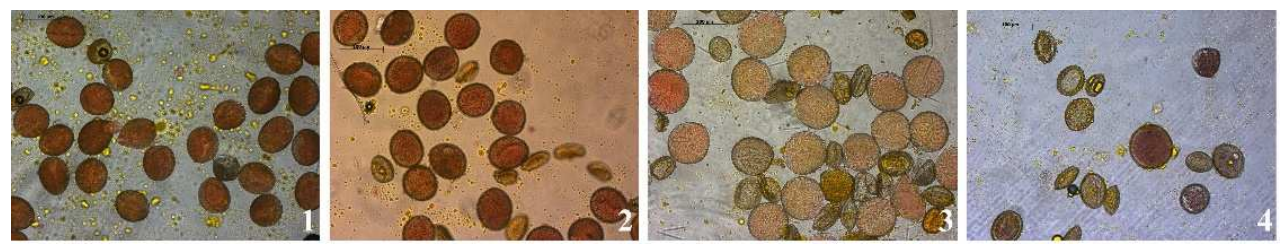

Fig. 3. Pollen of some species of the genus Hosta: 1 - H. albomarginata, $2-H$. decorata, $3-H$. sieboldiana, 4 - $H$. rectifolia.

The structure of the host leaf epidermis was studied. The leaves have clear-cut upper (adaxial) and lower (abaxial) parts of lamina. Outside the leaf is covered with the epidermis characterized by compact arrangement of cells, existence of cuticle and stomas. There were noted each of general and individual traits in the structure of epidermal cells for all the species. There were revealed differences between cells of upper and lower epidermis. On the adaxial part of leaf the epidermis consists of large thin-walled cells, skintight to each other, they are extended, from pentagonal to hexagonal form (fig. 4). Existence of larger epidermal cells on the adaxial part of leaf is an attribute of mesophyte. Stomas are oval and they are located at epidermal cells junctions. They are distributed by the ranks parallel to longitudinal axis of leaf and they are dip into epidermis. The stomatal apparatus of tetracytic type, guard cells are surrounded with four accessory cells - two of them are lateral ones and other two are polar. Such type is characteristic of monocotyledonous plants. There are more abaxial stomas (tab. 2) that allows reducing leakage of water during transpiration and enhancing gas exchange.

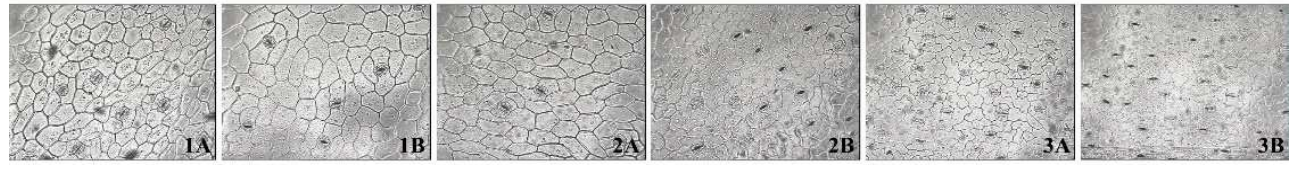

Fig. 4. 1. - H. albomarginata 2. - H. undulata 3. - H. lancifolia. Upper (a) and lower (b) leaf epidermis.

It was found that in H. albomarginata, H. plantaginea, H. undulata, and H. lancifolia, the leaf is amphistomatic, the stomata are located parallel to the longitudinal axis, and their number is $3-8$ times greater on the abaxial side than on the adaxial side of the leaf. In $H$. sieboldiana, $H$. decorata, the leaf is hypostomic. The aperigenic type of stomata in $H$. albomarginata, $H$. plantaginea, $H$. sieboldiana, $H$. decorata, tetraperegenic in $H$. undulata, $H$. lancifolia (see fig. 4). Mesophytic features in the structure of the epidermis are more pronounced in the species: $H$. albomarginata, $H$. plantaginea, $H$. undulata, $H$. lancifolia, xeromesophytic in $H$. sieboldiana, $H$. fortune, $H$. montana, $H$. rectifolia, $H$. crispula, $H$. kikutii, H. decorata. 
Table 1. Number of stomata per $1 \mathrm{~mm}^{2}$ of leaf surface

\begin{tabular}{|l|c|c|}
\hline \multirow{2}{*}{\multicolumn{1}{|c|}{ Species }} & \multicolumn{2}{|c|}{$\begin{array}{c}\text { stomata per } 1 \mathrm{~mm}^{2} \text { of leaf } \\
\text { surface, pcs. }\end{array}$} \\
\cline { 2 - 3 } & \multicolumn{2}{|c|}{$\mathrm{M} \pm \mathrm{m}$} \\
\cline { 2 - 3 } & $\begin{array}{c}\text { Upper } \\
\text { epidermis }\end{array}$ & $\begin{array}{c}\text { Lower } \\
\text { epidermis }\end{array}$ \\
\hline H. albomarginata & $13,3 \pm 0.1$ & $44 \pm 0.2$ \\
\hline H. undulata & $3 \pm 0.1$ & $25 \pm 0.2$ \\
\hline H. lancifolia & $5 \pm 0.2$ & $16,4 \pm 0.1$ \\
\hline H. decorata & $15 \pm 0.5$ & $50 \pm 0.2$ \\
\hline
\end{tabular}

Note. $\mathrm{M}$ is the arithmetic mean, $\mathrm{m}$ is the standard error.

\section{Conclusion}

The studied hosts successfully adapt to the conditions of the forest-steppe zone of Western Siberia from the early stages of the organ formation process. The manifestation of the sequential formation of rudimentary vegetative and generative organs in the monocarpic shoot is characteristic of the genotype of the species. Generative organs are formed in the spring-early summer growth period for $32-76$ days. The length of the growing season of the species is $98-112$ days. The reproductive capabilities of the host are realized partly due to seed reproduction and differ in species variability. Hosts are thermophilic and reproduce well vegetatively. The large leaf surface of the host contributes to the high transpiration capacity of plants, which makes it possible to distinguish them among the promising decorative leaf crops for meso - and xeromesophytic growing conditions with different degrees of illumination, which is often observed in urbanized ecosystems of the urban landscape of Western Siberia.

This work is performed within the state task of the Central Siberian Botanic Garden of the Siberian Branch of the Russian Academy of Science on the project № AAAA-A21121011290025-2 "Analysis of biodiversity, conservation and restoration of rare and resource plant species using experimental methods". During the preparation for the publishing there were used materials of the CSBS Siberian Branch of the Russian Academy of Science bioresource scientific collection "Collections of live plants on the field and glass-covered ground", UNU № USU 440534.

\section{References}

1. M. Witomska, A. Lukaszewska, A. Tyszkicwicz, Journal of Fruit Ornamental Plant Research 16, 371 (2008)

2. F. M. Kuperman, Plant morphophysiology (High School, Moscow, 1977)

3. K. Ezau, Anatomy of seed plants (Mir, Moscow, V.2, 1980)

4. L. L. Sedelnikova, Vestnik KGAU 11, 151 (2012)

5. L. L. Sedelnikova, Izvestiya Saratovskogo universiteta. Chemistry series. Biology. Ecology 19, 421 (2019) 